\title{
THE FUTURE SUSTAINABILITY OF MALAYSIAN HIGHER EDUCATION INSTITUTIONS: WHAT MATTERS MOST?
}

\author{
Hairuddin Mohd Ali*, Lasisi Abass Ayodele, and Mohd Burhan Ibrahim \\ Department of Social Foundations and Educational Leadership, International Islamic \\ University Malaysia, P.O. Box 10, 50728 Kuala Lumpur, Malaysia \\ *Corresponding author: hairuddin@iium.edu.my
}

Published online: 20 March 2019

To cite this article: Mohd Ali, H., Ayodele, L.A., and Ibrahim, M.B. (2019). The future sustainability of Malaysian higher education institutions: What matters most? Asian Academy of Management Journal, 24(Supp. 1), 171-186. https://doi.org/10.21315/ aamj2019.24.s1.12

To link to this article: https://doi.org/10.21315/aamj2019.24.s1.12

\begin{abstract}
The purpose of the study was to examine the relationship between the organisational quality management initiatives (OQMI) and organisational culture (OC) on the sustainability of Malaysian higher education institutions (SMHEI). The study utilised 263 top administrators' completed questionnaire survey from universities in Peninsular Malaysia. The statistical techniques employed in this study were descriptive statistics, confirmatory factor analysis (CFA), and a full-fledged structural equation modelling to address the research questions and hypotheses testing. The findings revealed that long-term strategic planning initiatives (LSPI) required a thorough revision; communication and decision-making, and organisational climate of Malaysian higher education institutions (MHEI) persisted as challenges in improving the SMHEI. It was also revealed that the implementation of balanced scorecard could enhance the effectiveness and efficiency of MHEI. This study provides a basis for future studies, particularly in the Peninsular Malaysia context. Theoretically, the study also found that not only leadership perspectives required further investigation but also the financial, customer, internal process, and learning and growth perspectives in the administration for SMHEI.
\end{abstract}

Keywords: balanced scorecard, sustainability, organisational climate, quality assurance, long-term strategic planning initiatives

(C) Asian Academy of Management and Penerbit Universiti Sains Malaysia, 2019. This work is licensed under the terms of the Creative Commons Attribution (CC BY) (http://creativecommons. org/licenses/by/4.0/). 


\section{INTRODUCTION}

The successful implementation of Organisational Quality Management Initiatives (OQMI) is one of the Malaysian government's priorities in public service institutions (Asim, 2001). These new quality management initiatives comprising quality assurance, long-term strategic planning, and balanced scorecard execution have been recognised as the most sought management tools in enhancing the quality of Malaysian higher education institutions (MHEI). The former Malaysian Higher Education Minister, Mohamed Khaled Nordin (2010, p. 5) asserted that "Malaysia is envisioned in becoming an educational hub of Asia", and therefore the future sustainability of MHEI is indeed exceedingly imperative. Therefore, strategies need to be articulated and executed effectively to face the future challenges particularly to honour the demand of quality higher education and to accomplish the goal of enticing 100,000 foreign students by the year 2020 .

\section{HIGHER EDUCATION INSTITUTIONS: UNDERSTANDING THE CHALLENGING ISSUES}

The consequences from world's globalisation is known to adversely affect the future sustainability of higher education institutions around the world. Several significant distressing effects are the enormous challenges facing by most higher education institution administrators to collaborate and pursue the approaches in retaining the institution's pride (and branding), and to sustain staff effectiveness and efficiency in maintaining and improving up to global education standards (Chamila \& Chandana, 2016; Wright, 2010). In general, every higher education institution administrators knows and pertinent to know "when quality improves sustainability increases" (Waheed, Khan, \& Veitch, 2011, p. 359). This, sometimes generates unwarranted anxieties nor motivation in the higher educational institutions.

In case of the sustainability of Malaysian higher education institutions (SMHEI), the scenario is almost similar to its counterparts around the world, particularly in encountering the inconsistent future direction (Velazquez, Munguia, \& Sanchez, 2005). However, there is absolutely a clear indication that enormous amount of annual financial allocations is being spent on improving the quality of MHEI. The operational and developmental expenditures allocated on quality aspects of MHEI have increased by RM3.9 billion in year 2010 compared to the allocations in 2007. United Nations Educational, Scientific and Cultural Organization (UNESCO, 2012 , p. 72) revealed that almost $90 \%$ of the expenditure went to public MHEI to improve the quality of teaching and learning as well as providing better facilities. With regard to this, the Malaysian government invested considerable amount of 
financial resources on educational development which significantly increased the number of public MHEI from 7 in 1984 to 20 in 2011 (Fernandez, 2010). Therefore, the main aim of this study was to enquire to what extent does the increase in expenditure on OQMI consequently enhances the quality of MHEI and simultaneously bolstering the future SMHEI. This led to the development of the conceptual framework of the study as illustrated in Figure 1.

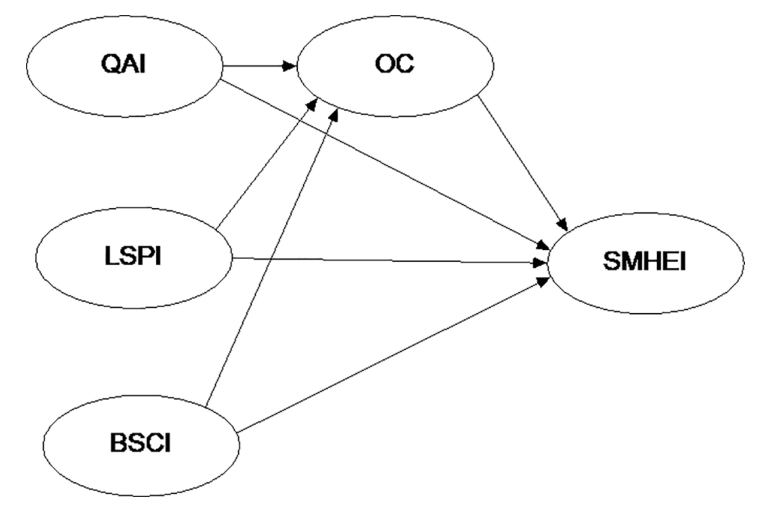

Figure 1. The conceptual framework of the study Source: Adapted from Lasisi (2016, p. 47)

As illustrated in Figure 1, the study hypothesised that the OQMI comprising Quality Assurance Initiatives (QAI), Long-Term Strategic Planning Initiatives (LSPI), and Balanced Scorecard Initiatives (BSCI) components directly and significantly influence the SMHEI. The study also sought to determine if Organisational Culture (OC) significantly influences the relationships between the components of OQMI (QAI, LSPI, and BSCI) and SMHEI. Therefore, the study sought to answer the following research questions:

RQ1: Are QAI and SMHEI directly and significantly related?

RQ2: Are LSPI and SMHEI directly and significantly related?

RQ3: Are BSCI and SMHEI directly and significantly related?

RQ4: Are OC and SMHEI directly and significantly related?

RQ5: Does OC significantly mediate the relationships between QAI and SMHEI?

RQ6: Does OC significantly mediate the relationships between LSPI and SMHEI?

RQ7: Does OC significantly mediate the relationships between BSCI and SMHEI? 


\section{LITERATURE REVIEW}

There are five hypothesised variables of interest in this research paper, namely SMHEI, QAI, LSPI, BSCI, and OC. The OQMI comprising QAI, LSPI and BSCI were hypothesised to affect SMHEI directly and indirectly through a mediator, OC. The discussions of the variables are in the following sections.

\section{Sustainability of Malaysian Higher Education Institutions (SMHEI)}

The literature has revealed that the greatest challenge to the university administrators is to ensure the future sustainability of higher education institutions mainly because it requires collaborative effort in retaining the institution's pride, staff effectiveness, and efficiency in maintaining global education standards (Chamila \& Chandana, 2016; Wright, 2010). Recent studies also indicated that the sustainability of higher education institutions could be attained if the organisational quality management initiatives focused on quality services (Kettunen, 2010, 2012; Kongkiti, Ketsarapong, Ooi, \& Shyu, 2012). Thus, quality assurance is indeed a critical theory that focuses on the idea of achieving high standard in services for the purpose of satisfying the stakeholders and the customers (Deming, 1982; Edwards, 2006). It is pertinent to know that "when quality improves sustainability increases" (Waheed et al., 2011, p. 359). Although the SMHEI is facing inconsistent direction (Velazquez et al., 2005) there is a clear indication that enormous amount of annual financial allocations is being spent on improving the quality of MHEIs. In this study, SMHEI was hypothesised as a dependent variable where QAI, LSPI, BSCI, and OC supposedly influenced it directly or indirectly. The related hypotheses of the study were generated in the following sections based on the causal relationships of the variables.

\section{Quality Assurance Initiatives (QAI)}

MHEI's quest for future sustainability in their pace for global competitiveness is an obligation to the nation. This study believes that QAI was one of the few factors that directly or indirectly affect the SMHEI. Pertaining to this, the quality gurus such as Deming, Juran, Crosby, Feigenbaum, Hayes, Ishikawa, Blanchard, and Joiner, to name a few, are the most important scholars in organisational management of quality (Rumane, 2011). A contemporary QAI scholar such as Kettunen $(2010,2012)$ is among the latest scholars who have tried to employ QAI in higher education institutions. In relation to QAI, Bhuiyan and Alam (2004) contended that Plan Do Check Act (PDCA) methodology (Kettunen, 2012; Nur Anisah, 2012) was employed in several Western higher education institutions quality assurance management initiatives and remarkably it is also a highly 
practiced standards of the Malaysian Qualification Agency (MQA), MS ISO 9000:94 as well as ISO9001:2000 of the British Standard Institution (BSI). PDCA is the standard operational policy in all MHEI as a guide for operational excellence and customer satisfaction (Noor Azman, Mohamed Zairi, \& Mahat, 2006; Tsim, Yeung, \& Leung, 2002). The hypothesis related to QAI is:

H1: There is a significant direct relationship between QAI and SMHEI.

\section{Long-Term Strategic Planning Initiatives (LSPI)}

The LSPI is based on ancient Chinese three stages military theory which dominated the business strategies at least for the last four decades. The theory was then employed in Johnson and Scholes' (1993) three stages model of strategic planning, namely strategic analysis, strategic choice, and strategic implementation. Similar theory was also employed by Bryson and Alston, (2005), Hambright and Diamantes (2004), Kettunen (2012), Knight (1997), Lasisi, Hairuddin, and Shuaibu (2013), and Tsiakkiros and Pashiardis (2002). In addition, Fidler (1996) emphasised that most educational models advocate utilising a broad-based ancient theory, in the sense that all the models of strategic planning relate to each other in their dimensionalities and explain a similar phenomenon. As strategic planning is based on continuous process for achievement of future plan, Fullan (2005, p. 22) relates strategic planning with sustainability of educational institution. This is consistent with Kaufman, Herman, and Waters (2002) who affirm that organisational climate of institution requires strategic planning for sustainability. The hypothesis related to LSPI is:

H2: There is a significant direct relationship between LSPI and SMHEI.

\section{Balanced Scorecard Initiatives (BSCI)}

Kaplan and Norton (2004) believe that BSCI is a prime need in quality management. Pertaining to this, Houston (2008) reiterated that BSCI can also bring improvement in services and achievement of success in higher education institutions. Interestingly, Nur Anisah (2012) also stressed that the employment of BSCI aims to mobilise strategically the leaders of MHEI and this is the main reason BSCI becomes the core of Malaysian higher education quality management initiatives. The essence of BSCI could be observed from four perspectives particularly learning and growth perspectives, customer perspectives, internal process perspectives, and financial perspectives. The hypothesis related to BSCI is:

H3: There is a significant direct relationship between BSCI and SMHEI. 


\section{Organisational Climate (OC)}

The OC is about the perceptions towards the organisational factors, particularly the organisational structure, job satisfaction, innovation initiatives, autonomy, reward, tolerance and conflict, internal support consideration, communication effectiveness, leadership, and resistance to change (Halpin \& Croft, 1963; Tagiuri, 1968; Jeswani \& Dave, 2012; Peña-Suárez, Muñiz, Campillo-Álvarez, FonsecaPedrero, \& García-Cueto, 2013; Owens, 1987). Most of the previous studies categorised $\mathrm{OC}$ into five factors, i.e., orientation, supervision, communication, decision making, and reward management. The importance of OC towards the sustainability of higher education institutions was also proved by Velazquez et al. (2005) followed by Litwin and Stringer (1968), Schneider, Brief, \& Guzzo (1996), and Noor Azman et al. (2006).

The issues of unfavourable tradition of $\mathrm{OC}$ in higher education institutions are unsettled circumstances and this matter is clearly expressed in Malaysian National Higher Education Strategic Plan 2007-2020. It is repeatedly stressed that higher education is one of the most important sectors that require favourable $\mathrm{OC}$ which can transform the organisation. For survivability in the presence of this complex OC of higher education institutions, the leadership's correct perceptions towards quality $\mathrm{OC}$ and high-performance organisation need to be seriously taken into consideration (Drucker, 1991). Therefore, the hypotheses related to OC as a mediator are as follows:

H4: There is a significant direct relationship between OC and SMHEI.

H5: OC significantly mediates the relationship between QAI and SMHEI.

H6: OC significantly mediates the relationship between LSPI and SMHEI.

H7: OC significantly mediates the relationship between BSCI and SMHEI.

\section{RESEARCH METHODOLOGY}

\section{Quantitative Approach}

This study employs a survey method approach in soliciting the information (Soltani, van der Meer, Williams, \& Lai, 2006) about OQMI influences on SMHEI. The major advantages of employing the quantitative approach are it ensures high levels of reliability, validity, and generalisability of the gathered data (Matveev, 2002; Muijs, 2011). Other justified reasons are the research was confirmatory in nature, the concept that was being measured used an ordinal scale, and the aim of the 
research was to classify features, to calculate, and to construct statistical models to explain what was observed. Subsequently, the quantitative data is more precise, able to test the hypotheses, and the researcher can remain objectively separated from the subject matter (Smith, 1983).

\section{Sampling}

In determining the sample size, this study purposely restricted the number of MHEI to eight established institutions. These eight institutions were considered established based on special characteristics defined by the researchers. Among others, the characteristics considered were the age of the institutions, size, and the accepted rankings of higher education institutions such as QS World University Ranking and Times Higher Education (THE). From the eight-selected established MHEIs, the study randomly selected 600 top-level academic administrators such as deans, deputy deans, directors, deputy directors, assistant directors, and head of departments (HODs) to complete the survey questionnaire of the study (Ferguson, 1981; Vockell \& Asher, 1995).

Table 1

The constructs and sources of items

\begin{tabular}{ll}
\hline $\begin{array}{l}\text { Variables } \\
\text { characteristics }\end{array}$ & Sources \\
\hline QAI (4)* & Deming (1982, 2013), Rumane (2011), Lasisi et al. (2013) \\
LSPI (3)* & Johnson and Scholes (1988), Lasisi, Hairuddin, and Shuaibu (2013) \\
BSCI) (4)* & Kaplan and Norton (2004) \\
OC (5)* & Jeswani and Dave (2012) \\
SMHEI (3)* & Wright (2010), Emanuel and Adams (2011), Velazquez et al. (2005), \\
& SAQ (2009)
\end{tabular}

Note: * values in the parentheses indicate the number of constructs for the respective variables

\section{Instrumentation}

The sources of the items used for the survey questionnaires are exhibited in Table 1. To ensure that the self-administered instruments are of highest quality, the study conducted two-stage pre-tests (Bourque \& Clark, 1992). Firstly, two educational management and leadership experts screened the items searching for ambiguities, unclear wordings, leading (and misleading) questions, and biases (Dillman, 1983). Secondly, the study managed to conduct a pilot testing of the adapted instrument by using a total of 100 participants. The values of reliability 
alphas $(\alpha)$ were between 0.75 and 0.98 , hence considered acceptable (Cortina, 1993; Nunnally \& Bernstein, 1994; Schmitt, 1996; Sijtsma, 2009). Consequently, the study resumed the data collection process among the deans, deputy deans, directors, deputy directors, assistant directors, and HODs.

\section{RESULTS}

The actual returned completed questionnaires were 277 (46.2\%). Following checking for missing data and outliers, the total usable questionnaires were 263, which were adequate for structural equation modelling (SEM) statistical analysis requirement (Hair, Black, Babin, \& Anderson, 2010). Confirmatory factor analysis (CFA) was applied for measurement models' validation before full-fledged SEM model was employed (Hair et al., 2010). AMOS 20.0 statistical software computer programme was employed for SEM analysis using the maximum likelihood in measuring the strength of the relationships between the variables of interest. Overall, the results indicate good fits for all measurement models (based on the given threshold values) and the convergent and discriminant validity were achieved among all the measurement models. The CFA results (initial and revised) for all measurement models are illustrated in Table 2.

Table 2

CFA Results of QAI, LSPI, BSCI, OC, and SMHEI

\begin{tabular}{|c|c|c|c|c|c|c|c|}
\hline \multirow{2}{*}{ Indices } & \multicolumn{2}{|c|}{ QAI } & \multicolumn{2}{|c|}{ LSPI } & \multicolumn{2}{|c|}{ SMHEI } & \multirow{2}{*}{ Threshold } \\
\hline & Initial & Revised & Initial & Revised & Initial & Revised & \\
\hline RMSEA & 0.114 & 0.067 & 0.129 & 0.064 & 0.124 & 0.071 & $0.03-0.08$ \\
\hline GFI & 0.709 & 0.918 & 0.679 & 0.960 & 0.725 & 0.936 & $>0.90$ \\
\hline CFI & 0.829 & 0.965 & 0.821 & 0.987 & 0.855 & 0.975 & $>0.90$ \\
\hline $\mathrm{X}^{2} / \mathrm{df}$ & 4.411 & 2.161 & 5.386 & 2.085 & 4.997 & 2.33 & $<3$ \\
\hline \multirow{2}{*}{ Indices } & \multicolumn{2}{|c|}{ BSCI } & \multicolumn{2}{|c|}{$\mathrm{OC}$} & \multicolumn{2}{|c|}{ SMHEI } & \\
\hline & Initial & Revised & Initial & Revised & Initial & Revised & Inreshold \\
\hline RMSEA & 0.126 & 0.074 & 0.117 & 0.070 & 0.124 & 0.071 & $0.03-0.08$ \\
\hline GFI & 0.646 & 0.900 & 0.729 & 0.948 & 0.725 & 0.936 & $>0.90$ \\
\hline CFI & 0.791 & 0.959 & 0.790 & 0.973 & 0.855 & 0.975 & $>0.90$ \\
\hline $\mathrm{X}^{2} / \mathrm{df}$ & 5.145 & 2.45 & 4.569 & 2.284 & 4.997 & 2.33 & $<3$ \\
\hline
\end{tabular}

Note $: \mathrm{CFI}=$ comparative fit index $; \mathrm{GFI}=$ goodness-of-fit index; RMSEA = root mean square error of approximation 
Prior to the hypotheses testing, the generated hypothesised structural model of the study as depicted in Figure 2 exhibits the unacceptable fit statistics: $\chi 2=823.183$ $(p<0.05), \chi 2 / \mathrm{df}=7.350, \mathrm{CFI}=0.781, \mathrm{GFI}=0.759, \mathrm{RMSEA}=0.162$, incremental fit index $(\mathrm{IFI})=0.783$, adjusted goodness-of-fit index $(\mathrm{AGFI})=0.671$, and TuckerLewis index $(\mathrm{TLI})=0.735$, which were out of the threshold values and therefore the model could not be utilised in assessing the strength of relationships between the variables of interest. This required the study to proceed to the modification of the hypothesised model. The reference to modification indices was pertinent to be taken into consideration before a revision to the model was carried out.



Figure 2. Generated hypothesised structural model of the study

In the following section, the results of the modification of the hypothesised structural model is presented and discussed. The new fit indices of the revised model are as follows: $\chi^{2}=199.402, p=0.000, \chi^{2} / \mathrm{df}=1.85$, CFI $=0.972$, RMSEA $=0.059$, TLI $=0.965$, GFI $=0.912$, AGFI $=0.875$, NFI $=0.941$ and IFI $=0.972$ (Table 3 ). Thus, the study clearly proved that the revised model (Figure 3) is better off in terms of its goodness of fit to the data. Now, the model is ready to be utilised in assessing the relationships between the variables of interest as well as to test the hypotheses of the study. 


\section{Hairuddin Mohd Ali et al.}

Table 3

Summary of goodness-of-fit indices of revised structural model

\begin{tabular}{lcccl}
\hline $\begin{array}{l}\text { Category of } \\
\text { goodness-of-fit }\end{array}$ & Indices & $\begin{array}{c}\text { Revised } \\
\text { values }\end{array}$ & $\begin{array}{c}\text { Threshold } \\
\text { values }\end{array}$ & Justification \\
\hline Absolute fit & RMSEA & 0.059 & $0.030-0.080$ & Hair et. al (2010) \\
Absolute fit & GFI & 0.912 & $>0.90$ & Kline (2011) \\
Incremental fit & CFI & 0.972 & $>0.90$ & Tabachnick and Fidell (2007) \\
Parsimonious fit & $\chi^{2} / \mathrm{df}$ & 1.846 & $<5$ & Sahari, Nik, Nik, and Marzuki (2004) \\
\hline
\end{tabular}

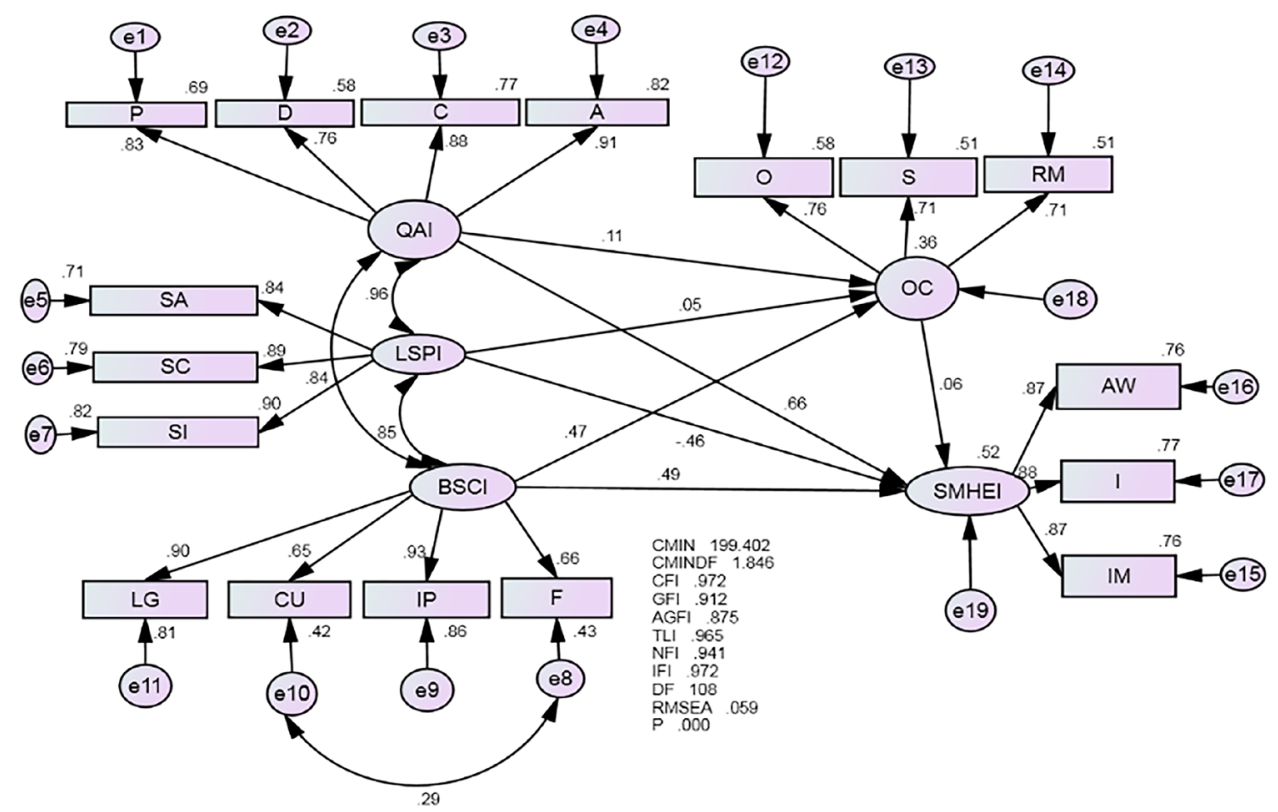

Figure 3. Revised hypothesised structural model of the study

In the following part, the results of the testing of the hypotheses with regard to their corresponding research questions are discussed. Surprisingly, the results were quite unexpected compared to what were hypothesised in this study. Only two out of seven hypotheses were supported as depicted in Table 4, while others were not supported. In terms of the direct relationships between the variables of interest, it was observed that only QAI and BSCI had a positive and significant direct relationship with SMHEI. 
Table 4

The results of data analyses and hypotheses tests

\begin{tabular}{|c|c|c|c|}
\hline $\begin{array}{l}\text { Research } \\
\text { questions and } \\
\text { hypotheses }\end{array}$ & Research questions and hypotheses statements & $\begin{array}{l}\text { Strength of } \\
\text { relationships }\end{array}$ & $\begin{array}{c}\text { Status/ } \\
\text { Decision }\end{array}$ \\
\hline RQ1 & $\begin{array}{l}\text { Are QAI and SMHEI directly and significantly } \\
\text { related? } \\
\text { There is a significant direct relationship between } \\
\text { QAI and SMHEI. }\end{array}$ & $0.66^{*}$ & $\begin{array}{c}\text { H1 } \\
\text { Supported }\end{array}$ \\
\hline RQ2 & $\begin{array}{l}\text { Are LSPI and SMHEI directly and significantly } \\
\text { related? } \\
\text { There is a significant direct relationship between } \\
\text { LSPI and SMHEI. }\end{array}$ & -0.46 & $\begin{array}{c}\mathrm{H} 2 \\
\text { Not supported }\end{array}$ \\
\hline RQ3 & $\begin{array}{l}\text { Are BSCI and SMHEI directly and significantly } \\
\text { related? } \\
\text { There is a significant direct relationship between } \\
\text { BSCI and SMHEI. }\end{array}$ & $0.49^{*}$ & $\begin{array}{c}\text { H3 } \\
\text { Supported }\end{array}$ \\
\hline RQ4 & $\begin{array}{l}\text { Are OC and SMHEI directly and significantly } \\
\text { related? } \\
\text { There is a significant direct relationship between } \\
\text { OC and SMHEI. }\end{array}$ & 0.06 & $\begin{array}{c}\mathrm{H} 4 \\
\text { Not supported }\end{array}$ \\
\hline RQ5 & $\begin{array}{l}\text { Does OC significantly mediate the relationship } \\
\text { between QAI and SMHEI? } \\
\text { OC significantly mediates the relationship } \\
\text { between QAI and SMHEI. }\end{array}$ & 0.006 & $\begin{array}{c}\text { H5 } \\
\text { Not supported }\end{array}$ \\
\hline RQ6 & $\begin{array}{l}\text { Does OC significantly mediate the relationship } \\
\text { between LSPI and SMHEI? } \\
\text { OC significantly mediates the relationship } \\
\text { between LSPI and SMHEI. }\end{array}$ & 0.003 & $\begin{array}{c}\text { H6 } \\
\text { Not supported }\end{array}$ \\
\hline RQ7 & $\begin{array}{l}\text { Does OC significantly mediate the relationship } \\
\text { between BSCI and SMHEI? } \\
\text { OC significantly mediates the relationship } \\
\text { between BSCI and SMHEI. }\end{array}$ & 0.028 & $\begin{array}{c}\mathrm{H} 7 \\
\text { Not supported }\end{array}$ \\
\hline
\end{tabular}

Note: *Greater than Kline (2011)

\section{DISCUSSION}

These particular results were indeed quite expected due to two main reasons: firstly, the QAI and BSCI variables are closely correlated theoretically and secondly, almost all public MHEIs embarked on these two OQMI in their respective higher education institution. However, it was very unfortunate where LSPI, which was considered as a very distinguished and significant "turn around" tool by the management gurus, failed in its bid to contribute to the SMHEI in this context of study. 
This might be due to several reasons that need further scientific investigations in the near future. However, Morshidi (2010) stressed out that the LSPI factor, particularly in Malaysian context, had witnessed tremendous challenges and changes. He reiterated that there are several evidences that LSPI was employed in MHEIs, but it was not completely accepted, implemented effectively and monitored, and not correctly practiced by all MHEIs as perceived by their administrators.

The most unsupported hypotheses came from the OC. In this study, it was hypothesised that OC was a mediator for QAI, LSPI, BSCI, and SMHEI. The hypothesis of OC directly and significantly related to SMHEI was not supported. The OC also failed to significantly mediate the relationships between QAI, LSPI, and BSCI with SMHEI. The findings were somewhat not in line with Jeswani and Dave (2012) and thus this was considered a new finding, which was not similar to any other results of OC. For more evidence, more investigations of OC functions in the Malaysian context of higher education institutions are needed in the future.

\section{THEORETICAL IMPLICATIONS}

In the context of MHEI, the study found that not only leadership perspectives required investigations, but also needed to be extended to financial, customer, internal process, and learning and growth perspectives. Cost indeed was one of the implications because costs incurred by the government on quality management initiatives are tremendous for SMHEI. Thus, poor reward management system may have weakened the relationship between OC and SMHEI. Finally, the findings had theoretically claimed that sustainability can be measured through three OQMI components. Evidence from construct validity and internal consistency on three OQMI components variables measuring the SMHEI had shown to be valid, reliable, and capable of explaining the SMHEI. Thus, the study has contributed theoretically towards SMHEI.

\section{Practical Implications}

The finding revealed the presence of significant direct relationships between QAI and BSCI with SMHEI although LSPI, which is a well-known turn around tool, was denied in its functions here. This implicates that to ensure the SMHEI, the administrations of all MHEI need to focus on these two factors (QAI and BSCI). LSPI could also be emphasised again and implemented correctly and effectively. Moreover, adequate supervision can add value to the SMHEI. Failing to supervise the administrative forces on QAI, LSPI, and BSCI in OC of MHEI might become a practical obstruction towards SMHEI. Nevertheless, implementation of QAI, 
LSPI, and BSCI could be the sources of assistance and strategies to the key players in improving the effectiveness and efficiency of OC for SMHEI. Finally, the stakeholders needed to consider rewarding the management as it was a crucial matter for improvement in developing the agenda for SMHEI. By rewarding the workers, it would eventually allow OC of MHEI to provide standards and conform to the value for educational costs, and satisfy the customers abundantly, which consequently improve the conditions for SMHEI.

\section{CONCLUSION}

The results from this study had contributed to the MHEI management body of knowledge, at least in the context of SMHEI. The implication of the study included theoretical and practical aspects as it enabled to enrich the relevant literature through the implementation of quantitative and multivariate analyses. Further studies can be done by including all public and private MHEIs for widening the scope of generalisability and authenticity of the theory. This study indicated the preliminary findings of OQMI and its relationship with SMHEI where OC was a mediator. This was an evidence that supported OQMI as a factor that matters most for future SMHEIs.

\section{REFERENCES}

Asim, M. (2001). Adopting quality management concepts in public service reform: The case of the Malaysian Public Service. Labour and Management in Development Journal, 2(6), 1-20.

Bhuiyan, N., \& Alam, N. (2004). ISO 9001:2000 Implementation. International Journal of Productivity and Performance Management, 53(1), 13-25. https://doi.org/ $10.1108 / 17410400410509923$

Bourque, L.B., \& Clark, V.A. (1992). Processing data: The survey example. Newbury Park, CA: Sage Publications. https://doi.org/10.4135/9781412985499

Bryson, J.M., \& Alston, F.K. (2005). Creating and implementing your strategic plan: A work book for public and non-profit organizations (2nd ed.). San Francisco, CA: Jossey Bass.

Chamila, R.P., \& Chandana, R.H. (2016). Integrating sustainability education into international marketing curricula. International Journal of Sustainability in Higher Education, 17(1), 123-148.

Cortina, J.M. (1993). What is coefficient alpha? An examination of theory and application. Journal of Applied Psychology, 78(1), 98-104. https://doi.org/10.1037/00219010.78.1.98

Deming, W.E (1982). Out of the crisis. Massachusetts, MA: The MIT Press. 
Deming, W.E (2013). The essential Deming: Leadership principles from the father of quality. New York, NY: McGraw-Hill Education-Europe.

Dillman, D. (1983). Mail and other self-administered questionnaires. In P. Rossi, J.D. Wright, \& A.B. Anderson (Eds.), Handbook of survey research (pp. 359-377). New York, NY: Academic Press. https://doi.org/10.1016/B978-0-12-5982269.50016-1

Drucker, P. (1991). The new productivity challenges. Harvard Business Review, 69(6), 72. Edwards, K.J. (2006). Total quality management in education. London: Kogan Page Ltd.

Emanuel, R., \& Adams, J.N. (2011). College students' perceptions of campus sustainability. International Journal of Sustainability in Higher Education, 12(1), 79-92. https://doi.org/10.1108/14676371111098320

Ferguson, G.A. (1981). Statistical analysis in Ph.D. education (5th ed.). New York, NY: McGraw-Hill.

Fernandez, J.L. (2010). An exploratory study of factors influencing the decision of students to study at Universiti Sains Malaysia, Kajian Malaysia, 28(2), 107-136.

Fidler, B. (1996). Strategic planning for school improvement. London: Pitman.

Fullan, M. (2005). Leadership and sustainability: System thinkers in action. California, CA: Corwin Press.

Hair, J.F., Black, W.C., Babin, J.B., \& Anderson, R.E. (2010). Multivariate data analysis (7th ed.). New Jersey, NJ: Prentice-Hall Inc.

Halpin, A.W., \& Croft, D.B. (1963). The organizational climate of schools (Series: Midwest Administration Center, University of Chicago, Studies in Educational Administration). Chicago, IL: Midwest Administration Center, University of Chicago.

Hambright, G., \& Diamantes, T. (2004). An analysis of prevailing K-12 educational strategic planning models. ProQuest Education Journals, 125(1), 97-103.

Houston, D. (2008). Rethinking quality and improvement in higher education. Quality Assurance in Education, 16(1), 61-79. https://doi.org/10.1108/ 09684880810848413

Jeswani, S., \& Dave, S. (2012). Impact of organizational climate on turnover intention: An empirical analysis on faculty members of technical education of India. International Journal of Business Management \& Research, 2(3), 26-44.

Johnson, G., \& Scholes, K. (1988). Exploring corporate strategy (2nd ed.). Hemel Hempstead, England: Prentice-Hall.

Johnson, G., \& Scholes, K. (1993). Exploring corporate strategy: Text and cases. Hemel Hempstead, England: Prentice-Hall.

Kaplan, R.S., \& Norton, D.P. (2004). Strategy mapping: Converting intangible assets into tangible outcomes. Boston, MA: Harvard Business School Press.

Kaufman, R., Herman, J., \& Waters, B. (2002). Educational planning: Strategic, tactical and operational. Langham, MD: Scarecrow Press.

Kettunen, J. (2010). Strategy process in higher education. Journal of Institutional Research, 15(1), 16-27.

Kettunen, J. (2012). External and internal quality audits in higher education. The TQM Journal, 24(6), 518-528. https://doi.org/10.1108/17542731211270089

Kline, R.B. (2011). Principles and practice of structural equation modeling. London: The Guilford Press. 
Knight, J. (1997). Strategic planning for school managers: A handbook of approaches to strategic planning and development for schools and colleges. London: Kogan Page.

Kongkiti, P., Ketsarapong, S., Ooi, K., \& Shyu, S.H.P. (2012). Sustaining higher education reforms: Knowledge and policy implications learned from Thailand. International Journal of Educational Management, 25(3), 284-301.

Lasisi, A.A. (2016). The effects of organizational quality management initiatives and mediating factor on the sustainability of Malaysian higher education institutions. Unpublished $\mathrm{PhD}$ dissertation, International Islamic University Malaysia.

Lasisi, A.A., Hairuddin, M.A., \& Shuaibu, H.U. (2013). Investigating the quality management initiatives in higher educational institutions on customer satisfaction. International Journal of Modern Business Issues of Global Market, 1(2), 12-25.

Litwin, G.H., \& Stringer, R.A. (1968). Motivational and organizational climate. Boston, MA: Graduate School of Business Administration, Harvard University.

Matveev, A.V. (2002). The advantages of employing quantitative and qualitative methods in intercultural research: Practical implications from the study of the perceptions of intercultural communication competence by American and Russian managers. Theory of Communication and Applied Communication, 1, 59-67.

Mohamed Khaled, N. (2010). Message from the Minister of Higher Education Malaysia. OIC education directory 2010/2011. Kuala Lumpur: OIC International Business Centre/Ramcel Median Sdn. Bhd.

Morshidi, S. (2010). Strategic planning directions of Malaysia's higher education: University autonomy in the midst of political uncertainties. High Education, 59(4), 461-473. https://doi.org/10.1007/s10734-009-9259-0

Muijs, D. (2011). Doing quantitative research in education with SPSS. Los Angeles, LA: Sage Publications. https://doi.org/10.4135/9781849203241

Noor Azman, A., Mohamed Zairi, \& Mahat, F. (2006). Quality HR-TQM model for higher education institutions. The Journal of Human Resource and Adult Learning, 2(1), $88-98$.

Nunnally, J.C., \& Bernstein, I.H. (1994). Psychometric theory (3rd ed.). New York, NY: McGrawHill.

Nur Anisah, A. (2012). Performance measurement in Malaysia's higher education. In PMA 2012 Conference, University of Cambridge, United Kingdom, 11-13 July 2012. Retrieved 15 February 2013 from http://www.performanceportal.org.

Owens, R.G. (1987). Organizational behavior in education (6th ed.). Boston, MA: Prentice Hall and Allyn and Bacon.

Peña-Suárez, E., Muñiz, J., Campillo-Álvarez, Á., Fonseca-Pedrero, E., \& García-Cueto, E. (2013). Assessing organizational climate: Psychometric properties of the CLIOR Scale. Psicothema, 25(1), 137-144.

Rumane, A.R. (2011). Quality management in construction projects. New York, NY: Taylor \& Francis Group.

Sahari, M., Nik, A.H., Nik, S., \& Marzuki, A. (2004). Teachers' orientation towards students' note taking: Scale validation. Journal Pendidikan Universiti Malaya, $24,61-72$. 
SAQ. (2009). Sustainability assessment questionnaire. Retrieved 21 January 2012 from http://www.ulsf.org/programs_saq.html

Schmitt, N. (1996). Uses and abuses of coefficient alpha. Psychological Assessment, 8(4), 350-353. https://doi.org/10.1037/1040-3590.8.4.350

Schneider, B., Brief, A., \& Guzzo, R. (1996). Creating a climate and culture for sustainable organizational change. Organizational Dynamics, 24(4), 7-19. https://doi. org/10.1016/S0090-2616(96)90010-8

Sijtsma, K. (2009). Reliability beyond theory and into practice. Psychometrika, 74, 169. https://doi.org/10.1007/s11336-008-9103-y

Smith, J.K. (1983). Quantitative versus qualitative research: An attempt to clarify the issue. Educational Researcher, 12(3), 6-13. https://doi. org/10.3102/0013189X012003006

Soltani, E., van der Meer, R., Williams, T.M., \& Lai, P. (2006). The compatibility of performance appraisal systems with TQM principles: Evidence from current practice. International Journal of Operations \& Production Management, 26(1), 92-112. https://doi.org/10.1108/01443570610637030

Tabachnick, B.G., \& Fidell, L.S. (2007). Using multivariate statistics (5th ed.). Boston, MA: Pearson Education.

Tagiuri, R. (1968). The concept of organizational climate. In R. Tangiuri, \& G.W. Litwin (Eds.), Organizational climate: Explorations of a concept (pp. 13-32). Boston, MA: Division of Research, Graduate School of Business Administration, Harvard University.

Tsiakkiros, A., \& Pashiardis, P. (2002). Strategic planning and education: The case of Cyprus. The International Journal of Educational Management, 16(1), 6-17. https://doi.org/10.1108/09513540210415505

Tsim, Y.C., Yeung, V.W.S., \& Leung, E.T.C. (2002). An adaptation to ISO9001:2000 for certified organizations. Managerial Auditing Journal, 17(5), 245-250. https://doi. org/10.1108/02686900210429669

UNESCO (United Nations Educational, Scientific and Cultural Organization). (2012). The impact of economic crisis on higher education. Bangkok: Asia and Pacific Regional Bureau for Education.

Velazquez, L., Munguia, N., \& Sanchez, M. (2005). Deterring sustainability in higher education institutions: An appraisal of the factors which influence sustainability in higher education institutions. International Journal of Sustainability in Higher Education, 6(4), 383-391. https://doi.org/10.1108/14676370510623865

Vockell, E.L., \& Asher, J.W. (1995). Educational research (2nd ed.). Upper Saddle River, NJ: Prentice Hall.

Waheed, B., Khan, F.I., \& Veitch, B. (2011). Developing a qualitative tool for sustainability assessment of HEIs. International Journal of Sustainability in Higher Education, 12(4), 355-368. https://doi.org/10.1108/14676371111168278

Wright, T. (2010). University presidents' conceptualizations of sustainability in higher education. International Journal of Sustainability in Higher Education, 11(1), 61-73. https://doi.org/10.1108/14676371011010057 